\title{
Prevalence of Swine Hemoplasmas Revealed by Real-Time PCR Using 16S rRNA Gene Primers
}

\author{
Yusaku WATANABE ${ }^{1,2,4)}$, Masatoshi FUJIHARA ${ }^{1,2)}$, Jin SUZUKI ${ }^{1)}$, Fumina SASAOKA ${ }^{1)}$, Kazuya NAGAI ${ }^{3)}$ and \\ Ryô HARASAWA ${ }^{1,2) *}$ \\ ${ }^{1)}$ Department of Veterinary Microbiology, Faculty of Agriculture, Iwate University, Morioka, Iwate 020-8550, Japan \\ ${ }^{2}$ Department of Applied Veterinary Science, The United Graduate School of Veterinary Sciences, Gifu University, Gifu, Gifu 501-1193, \\ Japan \\ 3) Cryobiofrontier Research Center, Faculty of Agriculture, Iwate University, Morioka, Iwate 020-8550, Japan \\ 4) Bremen Vet Center, Yahaba, Iwate 028-3602, Japan
}

(Received 2 March 2012/Accepted 29 April 2012/Published online in J-STAGE 22 May 2012)

ABSTRACT. Hemoplasma is a tribal name for epierythrocytic mycoplasmas including Mycoplasma suis and M. parvum which are currently recognized in pigs as causative of porcine hemoplasmosis. Here, we report a real-time PCR assay for differential detection of these swine hemoplasma species by using allelic primers in the $16 \mathrm{~S}$ rRNA gene, and its application to survey for hemoplasma infections in pigs. Universal primers and species-specific primers were designed and evaluated by using swine blood samples positive in hemoplasmas. Mycoplasma suis and M. parvum infections were both confirmed by universal primers, and mixed infections were clearly distinguished by species-specific primers. Further, we applied this real-time PCR assay to 120 swine blood specimens from clinically healthy pigs in eleven farms in Japan, and found six (5.0\%) were positive for M. suis and $18(15.0 \%)$ were positive for M. parvum, and three $(2.5 \%)$ were mixed infection by both hemoplasma species.

KEY WORDS: hemoplasma, mycoplasma, swine.

doi: 10.1292/jvms.12-0096; J. Vet. Med. Sci. 74(10): 1315-1318, 2012

Hemoplasmas are epierythrocytic procaryotes that include mycoplasma species transferred from the Eperythrozoon and Haemobartonella genera, based on their similarity of the $16 \mathrm{~S}$ rRNA sequences, and newly identified hemotropic mycoplasmas [2, 9]. They are uncultivable in vitro so far and causative of hemolytic anemia, resulting in icterus and pyrexia in various mammalian species. Two hemoplasma species, Mycoplasma suis and M. parvum, formerly Eperythrozoon suis and E. parvum, respectively, are currently known in pigs [14].

Mycoplasma suis is a causative agent of swine hemoplasmosis, previously called porcine eperythrozoonosis, of which symptoms are variable. In the acute form, anemia, icterus and anorexia are observed in sows [5], severe anemia and pyrexia in newborn and weaned piglets [2, 4]. Chronic infection following acute form may depress growth rate and increase susceptibility to other infectious diseases in feeder pigs, resulting to reproductive failures or immunosuppression in sows $[4,9,18]$. The clinical signs of $M$. parvum infection have not well been documented, despite severe anemia along with pyrexia in splenectomised pigs $[1,13]$.

Diagnosis of swine hemoplasmosis has been based on microscopic observation of the organisms on the surface of erythrocytes in Giemsa-stained blood smears, but this

\footnotetext{
*Correspondence to: Harasawa, R., Department of Veterinary Microbiology, Faculty of Agriculture, Iwate University, Morioka, Iwate 020-8550, Japan.

e-mail: harasawa-tky@umin.ac.jp

(C)2012 The Japanese Society of Veterinary Science
}

method is limited in acute infection, because the parasites are not always apparent unless the parasitemia is developed [10]. Serological tests including indirect hemagglutination (IHA) and enzyme-linked immunosorbent assay (ELISA) have also been applied for $M$. suis detection $[8,10]$, but they are not common because of difficulty in obtaining specific antigens. Polymerase chain reaction (PCR) using specific primers targeting the $16 \mathrm{~S}$ rRNA gene has most widely been used for screening various hemoplasmas [6, 12, 15-17]. Species identification of $M$. suis is usually depending on PCR $[3,7]$, but the identification of $M$. parvum has long been hampered due to lack of established strains maintained in vivo so far. This particular species was detected by realtime and end-point PCR from clinically healthy pigs in a commercial farm, and the nucleotide sequences of almost entire region of the $16 \mathrm{~S}$ rRNA and RNase P RNA genes were recently determined [17].

In the present study, we evaluated universal and speciesspecific primers for PCR to detect swine hemoplasmas by applying to six swine blood specimens, designated $\mathrm{A}$ through $\mathrm{F}$, shown positive in hemoplasma infection in our previous study [17]. To evaluate the primers for real-time PCR, we examined three sets of primers, consisting of an universal primer set Pig 16S and two species-specific primer sets, Parvum 16S specific for M. parvum and Suis $16 \mathrm{~S}$ specific for $M$. suis (Table 1). The six swine blood specimens infected with hemoplasmas were subjected to real-time PCR by using these primers as described previously [17].

All the six blood specimens were positive for hemoplasma infection by the real-time PCR using the universal Pig 16S primer set. The PCR products showed the melting 
Table 1. Primer sets and sequences of primer used in real-time and end-point PCR assays

\begin{tabular}{|c|c|c|c|c|}
\hline Primer set & Primer name & Primer sequence (5' to $\left.3^{\prime}\right)$ & Position & size \\
\hline \multirow{2}{*}{ Pig $16 \mathrm{~S}$} & Pig 16S F & $5^{\prime}$-ttt tag tgg caa acg ggc ga-3' & $60-79 * *$ & \multirow{2}{*}{$247 \mathrm{bp}$} \\
\hline & Pig 16S R & $5^{\prime}$-tca atc cca ttg cgg ctg tt-3' & $287-306 * *$ & \\
\hline \multirow{2}{*}{ Parvum 16S } & Parvum 16S F & $5^{\prime}-$ aac aca tat tta act tgc tc- $3^{\prime}$ & $100-119^{*}$ & \multirow{2}{*}{$137 \mathrm{bp}$} \\
\hline & Parvum 16S R & $5^{\prime}$-cat att cet att cat ccg cg-3' & $217-236^{*}$ & \\
\hline \multirow{2}{*}{ Suis 16S } & Suis $16 \mathrm{~S} \mathrm{~F}$ & $5^{\prime}-$ aac gca tac tta act tac tt-3' & $82-101 * *$ & \multirow{2}{*}{$138 \mathrm{bp}$} \\
\hline & Suis 16S R & $5^{\prime}$-cat act cet att tac ceg ct-3' & $200-219^{* *}$ & \\
\hline \multirow{2}{*}{ Parvum 16S-2 } & Parvum 16S F & $5^{\prime}-$ aac aca tat tta act tgc tc- $3^{\prime}$ & $100-119^{*}$ & \multirow{2}{*}{$484 \mathrm{bp}$} \\
\hline & Hemo 16S R & $5^{\prime}-\mathrm{cct}$ acg ctt cet tta $\operatorname{cgc} \mathrm{cc}-3^{\prime}$ & $546-565^{* *}$ & \\
\hline \multirow{2}{*}{ Suis $16 \mathrm{~S}-2$} & Suis $16 \mathrm{~S} \mathrm{~F}$ & $5^{\prime}$-aac gca tac tta act tac tt-3' & $82-101 * *$ & \multirow{2}{*}{$483 \mathrm{bp}$} \\
\hline & Hemo 16S R & $5^{\prime}-\mathrm{cct}$ acg ctt cet tta cgc cc-3' & $546-565 * *$ & \\
\hline
\end{tabular}

* Relative to the M. parvum Morioka 9 (AB610850) sequence. ** Relative to the M. suis Illinois (U88565) sequence.

temperature $(\mathrm{Tm})$ at $84.62 \pm 0.33^{\circ} \mathrm{C}$ in the melting experiments. Specimens A, B and C were positive in the real-time PCR using the species-specific Parvum 16S primer set, and the $T m$ was $80.38 \pm 0.13^{\circ} \mathrm{C}$. All the specimens except B were positive in the real-time PCR using species-specific Suis 16S primer set, with $T m$ at $81.36 \pm 0.14^{\circ} \mathrm{C}$ (Fig. 1).

Then, we performed end-point PCR by using the same primer sets as real-time PCR. The PCR consisted of $5 \mu l$ of DNA solution, $5 \mu l$ of $10 \times$ Buffer for KOD-Plus-Ver.2, $5 \mu l$ of $2 \mathrm{mM}$ dNTPs, $3 \mu l$ of $25 \mathrm{mM} \mathrm{MgSO}_{4}, 0.3 \mu l$ of forward primer, $0.3 \mu l$ of reverse primer $(50 \mathrm{pmol} / \mu l$ each), $1 \mu l$ of KOD -Plus- $(1 \mathrm{U} / \mu l)$ and water to a final volume of 50 $\mu l$. After the denaturation at $98^{\circ} \mathrm{C}$ for $2 \mathrm{~min}$, the reaction was carried out 30 cycles with denaturation at $98^{\circ} \mathrm{C}$ for 10 sec, annealing at $55^{\circ} \mathrm{C}$ for $30 \mathrm{sec}$ and extension at $72^{\circ} \mathrm{C}$ for $30 \mathrm{sec}$. The amplified products were fractionated by $2.5 \%$ agarose gel electrophoresis with a Quick-Load 100 bp DNA Ladder marker (New England BioLabs Inc., Ipswich, MA, U.S.A.), and photographed by the GelDoc-It Imaging system (UVP, Upland, CA, U.S.A.) after staining with $0.4 \mu \mathrm{g} /$ $\mathrm{m} l$ ethidium bromide.

By using the primer set Pig 16S, all the specimens produced a relevant sized band in the end-point PCR. In the case of Parvum 16S primer set, specimens A, B and C produced a relevant sized band, and in the case of Suis $16 \mathrm{~S}$ primer set, specimens $\mathrm{A}, \mathrm{C}, \mathrm{D}, \mathrm{E}$ and $\mathrm{F}$ produced a relevant sized band. All the end-point PCR results were consistent with real-time PCR (Fig. 2). In addition, the PCR products obtained by using species-specific primer sets were too small to determine the nucleotide sequence in a 3500 Genetic Analyzer (Applied Biosystems, Foster City, CA, U.S.A.).

Next, we explored two other primer sets, Parvum 16S2 and Suis 16S-2, consisting of species-specific forward primers and a common universal reverse primer bracketing about 500 bp portion of the 16S rRNA gene (Table 1), by subjecting all the six blood specimens to end-point PCR as described previously [16]. The amplified products were fractionated by $1.0 \%$ agarose gel electrophoresis with a 200 bp ladder DNA size marker (TaKaRa Bio., Otsu, Japan), and photographed as described above.

By using the primer set Parvum 16S-2, specimens A, $\mathrm{B}$ and $\mathrm{C}$ produced a relevant sized band to $M$. parvum in the end-point PCR. In the case of the Suis 16S-2 primer
Pig 16S:B

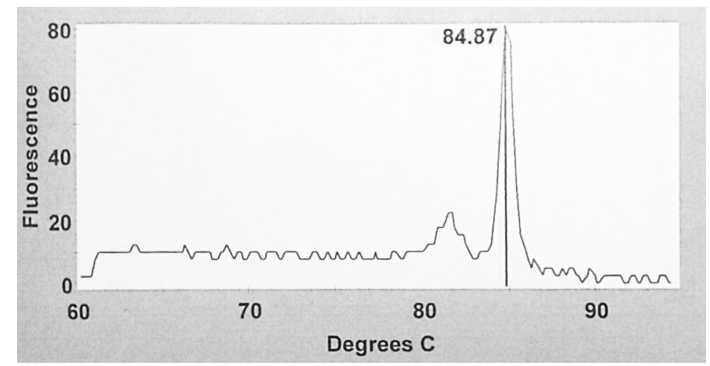

\section{Parvum 16S : B}

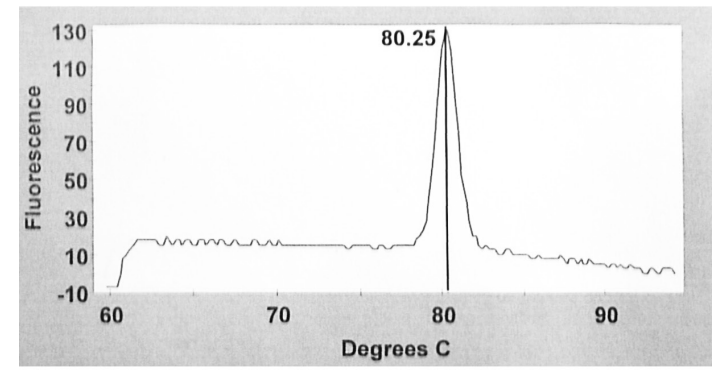

Suis $165: \mathrm{D}$

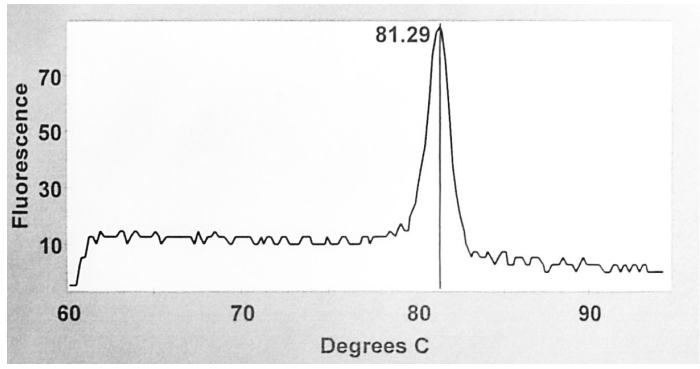

Fig. 1. Representative melting curves using primer sets Pig 16S (top: specimen B), Parvum 16S (middle: specimen B) and Suis 16S (bottom: specimen D).

set, specimens A, C, D, E and F produced a relevant sized band to $M$. suis, though the band of specimen A was faint to compare to others (Fig. 3). These PCR products were 
Pig 165

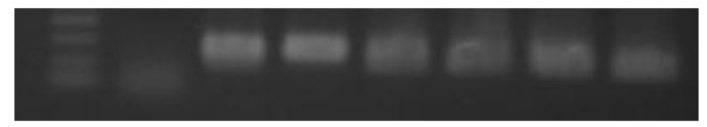

Parvum 16S

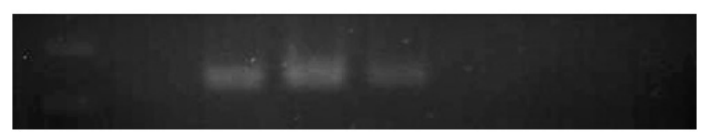

Suis 165

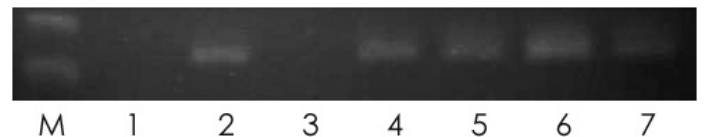

Fig. 2. Agarose gel electrophoresis of the PCR products amplified from six blood samples infected with hemoplasma using three primer sets, Pig 16S, Parvum 16S and Suis 16S. Lane M, DNA size marker (100 bp DNA ladder); lane 1, negative control; lane 2, A; lane 3, B; lane 4, C; lane 5, D 1; lane 6, E; lane 7, F.

further subjected to direct sequencing as described above. All the nucleotide sequences of PCR products obtained by using Parvum 16S-2 primer set were identical to $M$. parvum sequence. On the other hand, the nucleotide sequences of the PCR products obtained by using Suis $16 \mathrm{~S}-2$ were identified as $M$. suis, though sequencing of the specimen A was failed in our experiment. Taken together these results, existence of both $M$. parvum and $M$. suis was confirmed in specimen C, and this indicates the existence of mixed infection of both swine hemoplasmas that was not revealed by the universal primers. End-point PCR using Parvum 16S-2 and Suis 16S-2 primer sets were not sensitive as compared to real-time and end-point PCRs using Parvum 16S and Suis 16S primer sets for detection of swine hemoplasmas.

Our data support that the universal primers allow to detection of hemoplasma infection by real-time PCR as well as end-point PCR, but they were not able to distinguish the mixed infection of swine hemoplasmas.

Each hemoplasma species was detected by both real-time and end-point PCRs by using Parvum 16 S or Suis 16 S primer sets, but the real-time PCR with melting experiments was much more convenient than the end-point PCR. Thus, the real-time PCR using species-specific primers seemed more useful to evaluate the epidemiology of swine hemoplasmas.

Lastly, we applied real-time PCR in the same condition using species-specific primer sets to investigate the prevalence of swine hemoplasmas in 120 blood samples collected from clinically healthy pigs including 108 feeders and twelve sows raised in eleven different commercial swine farms in Japan. Of them, $18(15.0 \%)$ pigs in six $(54.5 \%)$ farms were positive for $M$. parvum, and six (5.0\%) pigs in one $(9.1 \%)$ farm were positive for $M$. suis. Mixed infections with both hemoplasma species were detected in three $(2.5 \%)$ blood samples.

Our results first demonstrated the existence of mixed
Parvum 16S-2

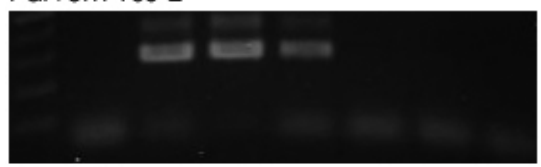

Suis 16 S-2

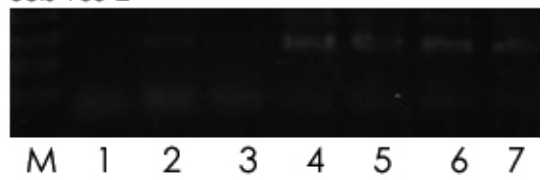

Fig. 3. Agarose gel electrophoresis of the PCR products amplified from six blood samples infected with hemoplasma using two primer sets, Parvum 16S-2 and Suis 16S-2. Lane M, DNA size marker (200 bp DNA ladder); lane 1, negative control; lane 2, A; lane 3, B; lane 4, C; lane 5, D 1; lane 6, $\mathrm{E}$; lane 7, F.

infection with $M$. parvum and $M$. suis in swine, and also revealed the prevalence of swine hemoplasma infections in Japanese farms nowadays. Mycoplasma suis infection causes panleucopenia in both piglets and sows and immunosuppression under the stressed conditions by parturition for sows or weaning for piglets [4]. This may lead to increased infections of respiratory and enteric diseases [6], and also it pertinent to consider this organisms affect as etiological agent with recent swine disease complex associated with emergent infectious diseases due to Porcine circovirus 2 infection etc. Besides, human infection with M. suis has been reported among swine farm workers in China [18] and should be considered in aspects of public hygiene. Although M. parvum has been thought relatively less pathogenic to swine [13], a clinical episode has been recorded in Japanese commercial swine farm in 1984 [11]. Thus, an in-depth investigation of swine disease complex is extremely urgent, because of high incidence of hemoplasma infection in the modern swine operation of this country.

\section{REFERENCES}

1. Barnett, S. F. 1963. Eperythrozoon parvum in pig in Kenya. Bull. Epizoot. Dis. Afr. 11: 185-195. [Medline]

2. Guimaraes, A. M. S., Santos, A. P., SanMiguel, P., Watler, T., Timenetsky, J. and Messick, J. B. 2011. Complete genome sequence of Mycoplasma suis and insights into its biology and adaption to and erythrocyte niche. PLOS ONE 6: e19574. [Medline] [CrossRef]

3. Harasawa, R., Mizusawa, H., Fujii, M., Yamamoto, J., Mukai, H., Uemori, T., Asada, K. and Kato, I. 2005. Rapid detection and differentiation of the major mycoplasma contaminants in cell cultures using real-time PCR with SYBR Green I and melting curve analysis. Microbiol. Immunol. 49: 859-863. [Medline]

4. Henderson, J. P., O'Hagan, J., Hawe, S. M. and Pratt, M. C. 1997. Anaemia and low viability in piglets infected with $E p$ erythrozoon suis. Vet. Rec. 140: 144-146. [Medline] [CrossRef]

5. Henry, S. C. 1979. Clinical observations on eperythrozoonosis. 
J. Am. Vet. Med. Assoc. 174: 601-603. [Medline]

6. Hoelzle, L. E. 2008. Haemotrophic mycoplasmas: recent advances in Mycoplasma suis. Vet. Microbiol. 130: 215-226. [Medline] [CrossRef]

7. Hoelzle, L. E., Adelt, D., Hoelzle, K., Heinritzi, K. and Wittenbrink, M. M. 2003. Development of a diagnostic PCR assay based on novel DNA sequences for detection of Mycoplasma suis (Eperythrozoon suis) in porcine blood. Vet. Microbiol. 93: 185-196. [Medline] [CrossRef]

8. Hoelzle, L. E., Hoelzle, K., Ritzmann, M., Heinritzi, K. and Wittenbrink, M. M. 2006. Mycoplasma suis antigens recognized during humoral immune response in experimentally infected pigs. Clin. Vaccine Immunol. 13: 116-122. [Medline] [CrossRef]

9. Messick, J. B. 2004. Hemotrophic mycoplasmas (hemoplasmas): a review and new insights into pathogenic potential. Vet. Clin. Pathol. 33: 2-13. [Medline] [CrossRef]

10. Messick, J. B., Cooper, S. K. and Huntley, M. 1999. Development and evaluation of a polymerase chain reaction assay using the 16S rRNA gene for detection of Eperythrooon suis infection. J. Vet. Diagn. Invest. 11: 229-236. [Medline] [CrossRef]

11. Minami, T. 1999. Eperythrozoonosis. pp. 295-296. In: Hyology and Hyoiatrics, 4th ed. (Kashiwazaki, M., Kubo, M., Kokue, E., Shimizu, M., Deguchi, E., Furuya, O. and Yamamoto, T. eds.), Kindaisyuppan, Tokyo (in Japanese).

12. Nishizawa, I., Sato, M., Fujihara, M., Sato, S. and Harasawa, R.
2010. Differential detection of hemotropic mycoplasma species in cattle by melting curve analysis of PCR products. J. Vet. Med. Sci. 72: 77-79. [Medline] [CrossRef]

13. Seamer, J. 1960. Studies with Eperythrozoon parvum Splitter, 1950. Parasitology 50: 67-80. [Medline] [CrossRef]

14. Splitter, E. J. 1950. Eperythrozoon suis n. sp. And Eperythrozoon parvum n. sp., two new blood parasites of swine. Science 111: 513-514. [Medline] [CrossRef]

15. Stoffregen, W. C., Alt, D. P., Palmer, M. V., Olsen, S. C., Waters, W. R. and Stasko, J. A. 2006. Identification of a haemomycoplasma species in anemic raindeer (Rangifer tarandus). J. Wildl. Dis. 42: 249-258. [Medline]

16. Watanabe, Y., Fujihara, M., Obara, H., Matsubara, K., Yamauchi, K. and Harasawa, R. 2010. Novel hemoplasma species detected in free-ranging sika deer (Cervus Nippon). J. Vet. Med. Sci. 72: 1527-1530. [Medline] [CrossRef]

17. Watanabe, Y., Fujihara, M., Obara, H., Nagai, K. and Harasawa, R. 2011. Two genetic clusters in swine hemoplasmas revealed by analyses of the 16S rRNA and RNase P RNA genes. J. Vet. Med. Sci. 73: 1657-1661. [Medline] [CrossRef]

18. Yuan, C. L., Liang, A. B., Yao, C. B., Yang, Z. B., Zhu, J. G., Cui, L., Yu, F., Zhu, N. Y., Yang, X. W. and Hua, X. G. 2009. Prevalence of Mycoplasma suis (Eperythrozoon suis) infection in swine and swine-farm workers in Shanghai, China. Am. J. Vet. Res. 70: 890-894. [Medline] [CrossRef] 